\title{
Soluble fibrinogen like protein 2 (sFGL2), the novel effector molecule for immunoregulation
}

\author{
Xin-guang Liu ${ }^{1, *}$, Yu Liu ${ }^{2, *}$ and Feng Chen ${ }^{1,3}$ \\ ${ }^{1}$ Department of Hematology, Qilu Hospital, Shandong University, Jinan, P. R. China \\ ${ }^{2}$ School of Chemistry and Pharmaceutical Engineering, Qilu University of Technology, Jinan, P. R. China \\ ${ }^{3}$ Capital Medical University Cancer Center, Beijing Shijitan Hospital, Beijing Key Laboratory for Therapeutic Cancer Vaccines, \\ Beijing, China \\ * These authors have contributed equally to this paper \\ Correspondence to: Feng Chen, email: chenfeng406@sina.com \\ Keywords: soluble fibrinogen-like protein 2; immunoregulation; transplantation; hepatitis; autoimmunity \\ Received: July 25, $2016 \quad$ Accepted: September 29, $2016 \quad$ Published: October 08, 2016
}

\section{ABSTRACT}

Soluble fibrinogen-like protein 2 (sFGL2) is the soluble form of fibrinogen-like protein 2 belonging to the fibrinogen-related protein superfamily. It is now well characterized that SFGL2 is mainly secreted by regulatory T cell (Treg) populations, and exerts potently immunosuppressive activities. By repressing not only the differentiation and proliferation of $\mathrm{T}$ cells but also the maturation of dendritic cells (DCs), sFGL2 acts largely as an immunosuppressant. Moreover, sFGL2 also induces apoptosis of B cells, tubular epithelial cells (TECs), sinusoidal endothelial cells (SECs), and hepatocytes. This mini-review focuses primarily on the recent literature with respect to the signaling mechanism of $5 F G L 2$ in immunomodulation, and discusses the clinical implications of SFGL2 in transplantation, hepatitis, autoimmunity, and tumors.

\section{INTRODUCTION}

Fibrinogen-like protein 2 (FGL2), also known as fibroleukin, is identified as a member of the fibrinogenrelated protein superfamily (fibrinogen-related domain, FRED) because of its homology with fibrinogen $\beta$ and $\gamma$ chains [1]. Members of this protein family also include fibrinogen, tenascin, ficolin, angiopoietin, and fibronectin, which are capable of adjusting the host's immune response [2-6]. The $f g l 2$ gene was originally cloned from cytotoxic T lymphocytes (CLTs), and the encoded glycoprotein shared a $36 \%$ homology to the $\beta$ and $\gamma$ chains of fibrinogen, and a $40 \%$ homology to the FRED of tenascin $[7,8]$. It is well known that FGL2 has two structurally different forms: the membrane bound FGL2 (mFGL2) and the soluble FGL2 (sFGL2). mFGL2, a 70 $\mathrm{kDa}$ type II transmembrane glycoprotein protein expressed on the surface of macrophages or endothelial cells, is a direct prothrombinase with serine protease activity which can cleave prothrombin into thrombin through a noncanonical pathway, thus exerting procoagulant activity in immune-associated coagulation [9-11]. By contrast, sFGL2 has a $50 \mathrm{kDa}$ weight and is highly expressed by $\mathrm{CD} 4+\mathrm{CD} 25+$ regulatory $\mathrm{T}$ cells (Tregs) [12-15].
Moreover, sFGL2 expressed by other Treg populations, including $\mathrm{CD} 8+\mathrm{CD} 45 \mathrm{RC}^{\text {low }} \mathrm{T}$ cells [16], $\mathrm{CD} 8 \alpha \alpha+$ suppressive intraepithelial lymphocytes (IELs) [17], and CD3+CD4-CD8- double negative $\mathrm{T}$ cells (DNTs) [12, 18], also accounts for a small proportion of sFGL2 origin. Therefore, sFGL2 might be a common effector molecule of many classes of Tregs. Functionally distinct from mFGL2, sFGL2 possesses abilities in immunomodulation and contradictory properties in tissue injuries $[15,19,20]$. Recently, a growing body of evidence indicated that FLG2 was involved in the pathogenesis of a variety of diseases such as pregnancy failure [21], tumor growth [22], viral infection [23-25], allograft rejection [26], and autoimmune disorders $[12,27]$. As the physiological function and the pathogenetic roles of mFGL2 have been well elucidated in some other papers $[20,28,29]$, this mini-review will focus on recent progress about the signaling mechanism of sFGL2 in immunomodulation. Furthermore, the characteristics and therapeutic potential of sFGL2 in transplantation rejection, viral hepatitis, autoimmunity, and tumors will also be discussed. 


\section{GENE ENCODING, PROTEIN STRUCTURE, AND EXPRESSION REGULATION OF SFGL2}

The flg2 gene, localized to the proximal region of chromosome 7q11.23 in humans and 5 in mice, is composed of two exons that are separated by one intron [11]. The longest open reading frame (ORF) of FGL2 encodes a protein of 439 amino acids in humans and 432 amino acids in mice, respectively. Transcription of human flg2 gene can produce 4 different mRNAs, 3 alternatively spliced variants, and 1 unspliced form [30]. The detailed cleavage manner leading to the function divergence between $\mathrm{mFLG} 2$ and sFGL2 remains unclear. Amino acid sequence analysis of FGL2 revealed an N-terminal hydrophobic motif which had a linear conformation, and a 229-amino-acid-long carboxyl-terminal domain known as FRED (Figure 1A) [9, 31, 32]. The serine 89 residue of the N-terminal domain was shown to be accounted for the procoagulant activity of mFGL2 [10], while FRED was reported to be critical for sFGL2-mediated immunoregulation [8]. A stretch of hydrophobic amino acids at N-terminus of FGL2 served as signal peptide for sFGL2 secretion, but how sFGL2 was cleaved and secreted remained unknown [11]. Liu and colleagues recently showed that glycosylations of the amino acids at positions of 172, 228, 256, and 329 were responsible for maintaining the solubility of sFGL2 [15]. sFGL2 in its natural state existed as an oligomer consisting of 4 monomers (Figure 1B) [33, 34]. Through inter-chain disulfide bond of cysteinesat amino acid positions 94, 97, 184 , and 187 at the central and $\mathrm{C}$ terminal region, sFGl2 monomers are assembled into dimers, and next dimers are further assembled into tetramers by inter-chain disulfide bonds with two additional cysteine pairs (Figure 1) [15]. Interestingly, monomeric sFLG2 has been found to exhibit greater immunosuppressive activity than native oligomer sFGL2 [15]. Similar to the structure in the D domain of fibrinogen, two pairs of cysteins located in the FRED of sFGL2, Cys ${ }^{206}{ }^{2} \mathrm{Cys}^{235}$ and $\mathrm{Cys}^{364}-\mathrm{Cys}^{377}$, could form intrachain loops which might affect the biological activity of sFGL2 [15].

In contrast with mFGL2 which is expressed by endothelial cells, epithelial cells, macrophages, and dendritic cells (DCs) [35], sFGL2 has been found to be secreted by $\mathrm{CD}^{+} \mathrm{CD} 25^{+}$Tregs, $\mathrm{CD} 8^{+} \mathrm{CD} 45 \mathrm{RC}^{\text {low }} \mathrm{T}$ cells, IELs, and DNTs, but not by T helper (Th) cells and B cells $[7,12,16,17,33,36]$. Various transcription factors, such as Ets, TCF1, CEBP, AP1, Ikaros or SP1, can bind FGL2 promoter through cis element consensus sequences, contributing to the differential transcription and expression pattern of FGL2 based on different cell types [11]. More specifically, members of the Ets transcription factor family are crucial for FGL2 expression in vascular endothelium, whereas Ikaros along with TCFI account for FGL2 transcription in lymphocytes [37]. Additionally, CEBP/a is responsible for the constitutive expression of FGL2 in hepatocytes, while recruitment of $\mathrm{CEBP} / \mathrm{b}$ contributes to the induction of this gene in macrophages $[11,38]$.

ROLE OF SFGL2 IN IMMUNO-REGULATION

\section{sFGL2 and antigen-presenting cells}

It has been well established that sFGL2 lacks procoagulant activity of mFGL2, but rather functions as a multimodality regulatory of immunosuppression [8]. sFGL2 cannot bind to fibrinogen receptors such as Mac1, ICAM-1 or Toll-like receptor 4 (TLR4). Up to now, two receptors, Fc $\gamma$ receptor (Fc $\gamma \mathrm{R}$ ) IIB and Fc $\gamma$ RIII, have been identified as the mediator of sFGL2 function [39]. Fc $\gamma$ RIIB has an immunoreceptor tyrosine-based inhibition motif (ITIM) in its intracytoplasmic domain [40], and is the only Fc $\gamma R$ that has an inhibitory function [41]. On the contrary, Fc $\gamma$ RIII contains an immunoreceptor tyrosinebased inhibition motif (ITAM) that mediates the activating signaling [42]. After binding to Fc $\gamma$ Rs, sFGL2 has distinct biological effects on diverse cell types, which might be due to different expression ratio of Fc $\gamma$ RIIB to Fc $\gamma$ RIII on cellular surface, or different affinities of sFGL2 to that two kinds of Fc $\gamma$ Rs [43].

Antigen-presenting cells (APCs), including DCs, monocytes/macrophages, and B cells, play important roles not only in innate immunity but also in adaptive immune responses. By binding to Fc $\gamma$ RIIB and Fc $\gamma$ RIII, sFGL2 can adjust the antigen presentation ability of APCs. Target deletion of FGL2 in mice resulted in increased number of Ab-producing $\mathrm{B}$ cells and DCs in spleen [12]. Moreover, anti-viral B cell responses following Lymphocytic Choriomeningitis Virus WE infection were remarkably enhanced in $f g l 2^{-/}$- mice, which was beneficial to virus elimination [44]. Following lipopolysaccharide (LPS) stimulation, elevated levels of CD80 and major histocompatibility complex (MHC) II as well as decreased ratio of apoptosis were observed on DCs from $f g l 2^{-/-}$mice [12].

On the contrary, exogenous sFGL2 could lead to reduced expression of CD80 and $\mathrm{MHC}$ II on bone marrow (BM)-derived DCs, while levels of MHC I and CD86 on DCs were not challenged [8]. Given the crucial roles of co-stimulatory molecules played in the initiation of immune response by $\mathrm{T}$ and $\mathrm{B}$ cells, it is not surprising that modulation of these molecules on DCs by sFGL2 would have profound effect on $\mathrm{T}$ cell immunity of the adaptive immune system. Studies by Chan revealed that sFGL2 could prevent the maturation of DCs and reduce their capacity to stimulate $\mathrm{T}$ cell proliferation [8]. Fc $\gamma$ RIIB and FcyRIII are also expressed by monocytes/macrophages, but in what way they are modulated by sFGL2 still needs further investigation. 
Table 1: sFGL2-expressing Tregs.

\begin{tabular}{|c|c|c|c|c|}
\hline & $\mathrm{CD4}^{+}$Tregs & CD8 $^{+}$Tregs & IELs & DNTs \\
\hline $\begin{array}{l}\text { Immunophenotypic } \\
\text { identification }\end{array}$ & $\mathrm{CD} 4^{+} \mathrm{CD} 25^{\text {high }} \mathrm{Foxp}^{+}$ & CD45RC $\mathrm{R}^{\text {low }}$ & $\mathrm{CD} 8 \alpha \alpha+$ & $\mathrm{CD}^{+}{ }^{+} \mathrm{CD} 4^{-} \mathrm{CD} 8^{-}$ \\
\hline $\begin{array}{l}\begin{array}{l}\text { Suppressive, pro- } \\
\text { apoptotic, } \\
\text { cytolysis molecules }\end{array} \\
\end{array}$ & $\begin{array}{l}\text { CTLA-4, LAG3, LAP, TIGIT, } \\
\text { IL-10, TGF- } \beta \text {, IL-35, PD- } \\
\text { 1, CD95, GITR, galectin 1, } \\
\text { granzymes }\end{array}$ & $\begin{array}{l}\text { CTLA-4, IL-10, TGF- } \beta \text {, } \\
\text { IDO, FasL, perforin }\end{array}$ & $\begin{array}{l}\text { TGF- } \beta 3 \text {, LAG3, FasL, } \\
\text { CD69, granzymes, } \\
\text { NK-like receptors }\end{array}$ & $\begin{array}{l}\text { CTLA4, FasL, } \\
\text { perforin, }\end{array}$ \\
\hline Origin & $\begin{array}{l}\text { Thymus (nTreg) or periphery } \\
\text { (iTreg) }\end{array}$ & Thymus & Intestinal epithelium & $\begin{array}{l}\begin{array}{l}\text { Thymus } \\
\text { periphery }\end{array} \\
\end{array}$ \\
\hline Mechanisms & $\begin{array}{l}\text { Attenuation of DC function, } \\
\text { inhibition of Th1 and } \\
\text { Th17 development, anti- } \\
\text { inflammatroy apoptosis } \\
\text { induction, Breg induction }\end{array}$ & $\begin{array}{l}\text { Perforin-mediated } \\
\text { cytolysis, FasL-induced } \\
\text { apoptosis, induction of } \\
\text { CD4 }{ }^{+} \text {Tregs, inhibitory } \\
\text { cytokine-mediated } \\
\text { suppression }\end{array}$ & 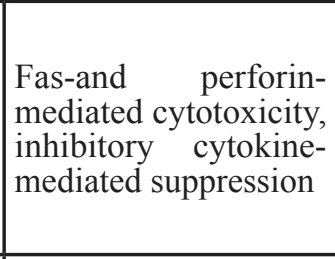 & \begin{tabular}{|l|} 
Perforin- \\
mediated \\
cytolysis, \\
FasL-induced \\
apoptosis, \\
Attenuation of \\
DC function \\
\end{tabular} \\
\hline References & {$[12-14,70,106]$} & {$[16,107]$} & {$[17,108,109]$} & {$[12,107]$} \\
\hline
\end{tabular}

IELs, intraepithelial lymphocytes; DNTs, double negative T cells; CTLA-4, cytotoxic T lymphocyte-associated antigen 4; LAG3, lymphocyte activation gene 3; LAP, latency-associated peptide; TIGIT, T-cell Ig and ITIM domain; IL, interleukin; TGF, transforming growth factor; PD-1, programmed cell death 1; GITR, glucocorticoid-induced TNF-receptor-related protein; IDO, indoleamine 2,3-dioxygenase; FasL, Fas ligand; nTregs, natural Treg; iTreg, induced Treg.

\section{SFGL2 and T cells}

It has been widely recognized that sFGL2 acts as an important effector molecule of $\mathrm{CD} 4{ }^{+} \mathrm{CD} 25^{+}$Tregs in their development and function. Previous study has shown that $\mathrm{CD} 4{ }^{+} \mathrm{CD} 25^{+}$Tregs were more abundant in $f g l 2^{--}$mice, but their ability to suppress effector $\mathrm{CD}^{+} \mathrm{T}$ cell proliferation was significantly impaired. In contrast to the blockade of IL-10, TGF- $\beta$ or CTLA-4 which was ineffective or weak in $\mathrm{CD} 4{ }^{+} \mathrm{CD} 25^{+}$Treg activity inhibition, administration of sFGL2 neutralizing antibody could abolish the suppressive activity of $\mathrm{CD} 4^{+} \mathrm{CD} 25^{+}$Tregs in vitro in a dose dependent manner [12]. In addition, Th cells from $f g l 2^{--}$mice were polarized toward a Th1 phenotype [12]. FGL2 and PD-1 have been identified as the most upregulated genes in perinatally generated $\mathrm{CD} 4{ }^{+} \mathrm{CD} 25^{+}$Tregs which play critical roles in maintaining self-tolerance during life [45]. More recently, Joller et al. revealed that sFGL2 was indispensable for the ability of the novel identified TIGIT $^{+} \mathrm{CD} 4{ }^{+} \mathrm{CD} 25^{+}$Treg cell subset to suppress $\mathrm{Th} 1$ and Th17 cell response [46]. Taken together, sFGL2-mediated immunoregulation might be crucial for the maintenance of Th cell homestasis.

Aside from $\mathrm{CD}^{+} \mathrm{CD} 25^{+}$Tregs, other Treg cell subsets were also capable of producing sFGL2. Li and colleagues found that FGL2 expressed by tolerogenic $\mathrm{CD} 8^{+} \mathrm{CD} 45 \mathrm{RC}^{\text {low }}$ Tregs was an important mediator of $\mathrm{CD} 8^{+}$Treg suppression [16]. An obvious expression of FGL2 in DNTs has been observed, and FLG2 deprivation in DNTs was associated with the loss of suppressive activity $[12,18]$. In addition, Denning demonstrated that FGL2 mRNA was highly expressed in TCR $\alpha \beta^{+} \mathrm{CD} 8 \alpha \alpha$ intestinal IELs [17], a CD8 ${ }^{+} \mathrm{T}$ cell subtype critical for the establishment of normal mucosal tolerance [47]. But the precise effect of sFGL2 expressed by TCR $\alpha \beta^{+} \mathrm{CD} 8 \alpha \alpha$ IELs on mucosal immunity has not been clarified yet. Collectively, these data suggest that sFGL2 is a common immunosuppressive mediator of many Treg subsets (Table 1).

\section{sFGL2 and regulatory $B$ cells}

B cells play important roles in innate and adaptive immunity. Over the past decade, a proportion of B cells with suppressive function have gained substantial attention. That B cell subset is collectively known as regulatory B cells (Bregs) which act as modulators of the immune response against pathogens and autoantigens. Bregs exert their regulatory effect through producing anti-inflammatory cytokines, inducing the apoptosis of effector T cells, and promoting the differentiation of $\mathrm{CD} 4^{+} \mathrm{CD} 25^{+} \mathrm{Foxp}^{+}$Tregs $[48,49]$. More recently, Bezie and co-workers demonstrated that adoptive transfer of splenocytes from FGL2-overexpressed rats into animals that were transplanted with cardiac allografts could prevent acute and chronic rejection. FGL2-overexpression in donor rats favored the proliferation of CD45 RA ${ }^{+}$Bregs in spleen, and these Bregs were the main cells responsible for the induction of allograft tolerance [50].

\section{Roles of sFGL2 in apoptosis}

sFGL2 also functions as a proapoptotic effector molecule besides its well identified immunosuppressive activity. Through binding to the inhibitory Fc $\gamma$ RIIb, sFGL2 could promote cellular apoptosis of sinusoidal 
endothelial cells (SEC) and hepatocytes, leading to hepatic reperfusion injury [51]. In a porcine kidney autotransplantation model, peripheral and local sFGL2 levels during the recovery of renal ischemia reperfusion injury were significantly elevated [51]. Additionally, in renal allograft recipients with acute rejection (AR), serum levels of sFGL2 were shown to be increased to an extent dependent on pathological severity [52]. Further study by the same group revealed that in renal allograft patients with AR, elevated sFGL2 could induce tubular epithelial cell (TEC) apoptosis [53]. sFGL2 was also involved in the induction of B cell apoptosis. Shalev et al. reported that Fc $\gamma$ RIIb positive A20 B cells treated with recombinant sFGL2 would undergo obvious apoptosis process [12]. B cells are composed of B1 cells, B2 cells, and Bregs [54]. These B-cell subsets play distinct and non-redundant roles in immunoregulation. Nonetheless, the impact of sFGL2 on these different B-cell subsets still awaits further exploration.

\section{sFGL2-related signaling pathways}

It has been well established that sFGL2 exerts multiple effects by interacting with its receptors, Fc $\gamma$ RIIb and FcyRIII. Nevertheless, the downstream signaling pathways after ligand-receptor binding still remain unilluminated. According to previously identified signaling pathways that can be triggered by Fc $\gamma \mathrm{R}$ crosslinking, several pathways are proposed to be related to the function of sFGL2 (Figure 2).

\section{ITAM/ITIM-dependent signaling pathway}

Fc $\gamma$ RIII is one of the activating Fc $\gamma$ Rs composed of a ligand-binding $\alpha$-chain and a single-transducing $\gamma$-chain dimer which carries an immunoreceptor tyrosine based activating motif (ITAM). While Fc $\gamma$ RIIb is a single $\alpha$-chain inhibitor receptor which contains an immunoreceptor tyrosine based inhibitory motif (ITIM) in its cytoplasmic domain [41]. To date, our existing knowledge about the Fc $\gamma \mathrm{R}$-related pathways are primary derived from crosslinking of Fc $\gamma$ Rs by immune complexes (ICs) $[41,55]$. Fc $\gamma$ RIII crosslinking by ICs induces tyrosine phosphorylation of the ITAM in the receptorassociated adaptor molecules by kinases of the SRC family. This creates SRC homology 2 (SH2) docking sites for SYK-family kinases, which subsequently activates a variety of downstream signal-transduction molecules such as phosphoinositide 3-kinase (PI3K), multimolecular adaptor complexes, son of sevenless homologue (SOS), or the linker for activation of T cells (LAT). The generation of phosphatidylinositol-3,4,5-trisphosphate $(\operatorname{Ptdlns}(3,4,5)$

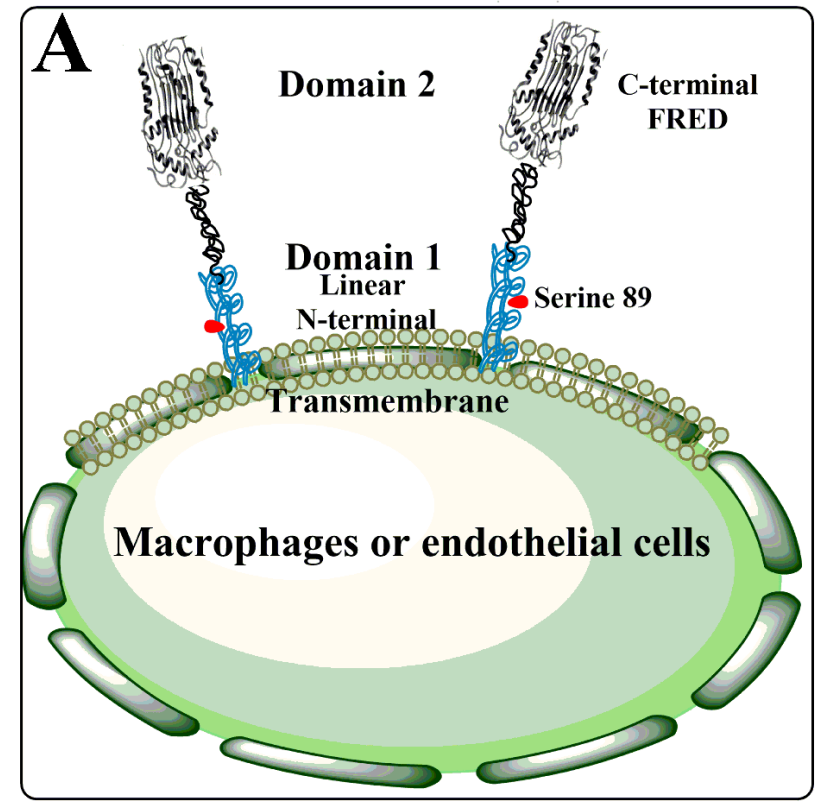

membrane bound FGL2

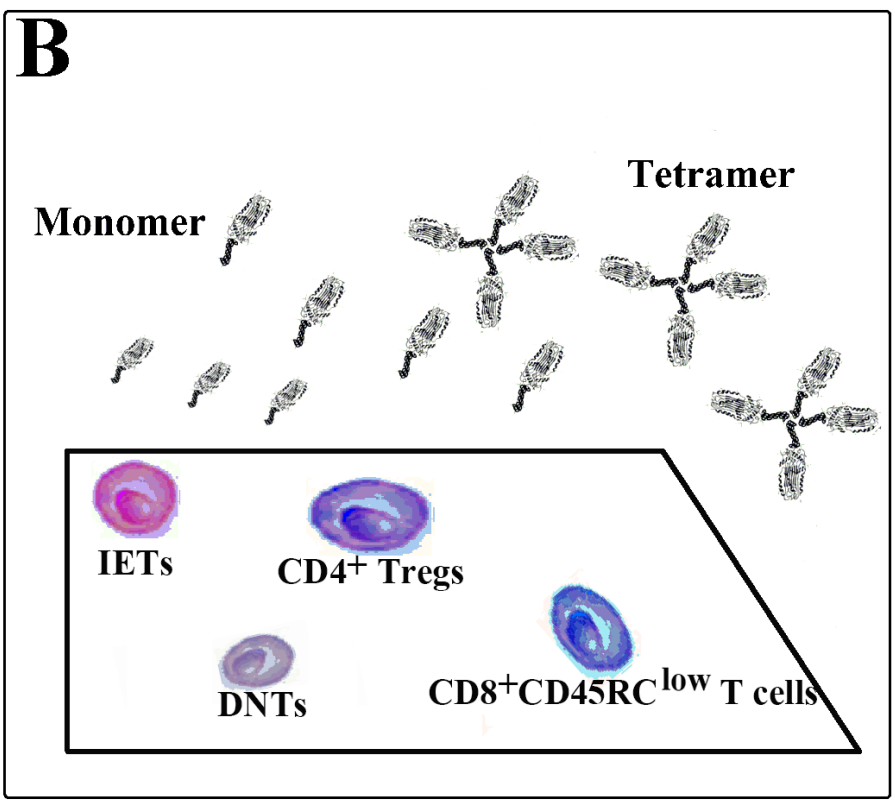

soluble FGL2

Figure 1: Schematic view of the two forms of FGL2. A. Membrane bound FGL2 (mFGL2) is a type II transmembrance glycoprotein expressed by macrophages or endothelial cells. The N-terminal linear coiled-coil domain (Serine 89) of mFGL2 is responsible for its prothrombinase activity, while function of C-terminal FRED domain remains unclarified. B. Soluble FGL2 (sFGL2) lacking the N-terminal hydrophobic sequence is mainly secreted by $\mathrm{CD} 4{ }^{+} \mathrm{CD} 25^{+}$Tregs. sFGL2 expressed by $\mathrm{CD} 8^{+} \mathrm{CD} 45 \mathrm{RC}^{\text {low }} \mathrm{T}$ cells, $\mathrm{CD} 8 \alpha \alpha^{+}$suppressive intraepithelial lymphocytes (IELs), and $\mathrm{CD}^{+} \mathrm{CD} 4 \mathrm{CD} 8$ - double negative $\mathrm{T}$ cells (DNTs) also accounts for a small proportion of sFGL2 origin. sFGL2 in its natural state exists as an oligomer consisting of 4 monomers. 
P3) by PI3K can recruit Bruton's tyrosine kinase (BTK) and phospholipase $\mathrm{C} \gamma$ (PLC $\gamma$ ), which leads to the release of calcium from the endoplasmic reticulum (ER). Intracellular calcium level increase can induce a number of downstream signaling events and trigger multiple cellular activities [56, 57]. Apart from calcium-dependent pathway, the RAS-RAF-MAPK-pathway can be activated through SOS bound to Grb2 that is recruited on phosphorylation of SHC, and is of critical importance for cell activation following crosslinking of the activating Fc $\gamma$ Rs.

Crosslinking of the inhibitory Fc $\gamma$ RIIb by ICs can dampen the activating pathways by interfering with the generation of key intermediates such as Ptdlns(3,4,5)P3. Phosphorylation of the ITIM motif in the cytoplasmic portion of Fc $\gamma$ RIIb by LYN leads to the recruitment of the SH2-domain-containing inositol-5-phosphatase (SHIP) and the hydrolysis of Ptdlns(3,4,5)P3 into Ptdlns $(4,5)$ P2, which ultimately inhibits recruitment of pleckstrin homology (PH)-domain containing proteins such as BTK and PLC $\gamma$, and thereby attenuating ITAM-signalingmediated calcium release and downstream effector function [58]. Moreover, the RAS-RAF-MAPK signaling pathway could also be inhibited by recruitment of SHC tyrosine-phosphorylated SHIP.

\section{ITAM/ITIM-independent signaling pathway}

It was reported a decade ago that isolated triggering of Fc $\gamma$ RIIb could induce B cell apoptosis [59]. Similarly, homo-oligomerization Fc $\gamma \mathrm{RIIb}$ would result in elevated levels of B-cell death, and it was demonstrated later that a signaling pathway involving the cABL kinase family, BTK and JUN N-terminal kinase (JNK), but independent of SHIP and ITIM, was responsible for this phenotype $[60,61]$. Furthermore, co-engagement of FcyRIIb and BCR in SHIP-/- B cells also led to apoptosis [59, 62]. Nevertheless, what we know about the impact of sFGL2 on ITIM-independent pathway is relatively rare, and further investigation is needed to verify the relationship between the signaling pathway and sFGL2-mediated apoptosis in B cells, TECs, SECs, or hepatocytes.

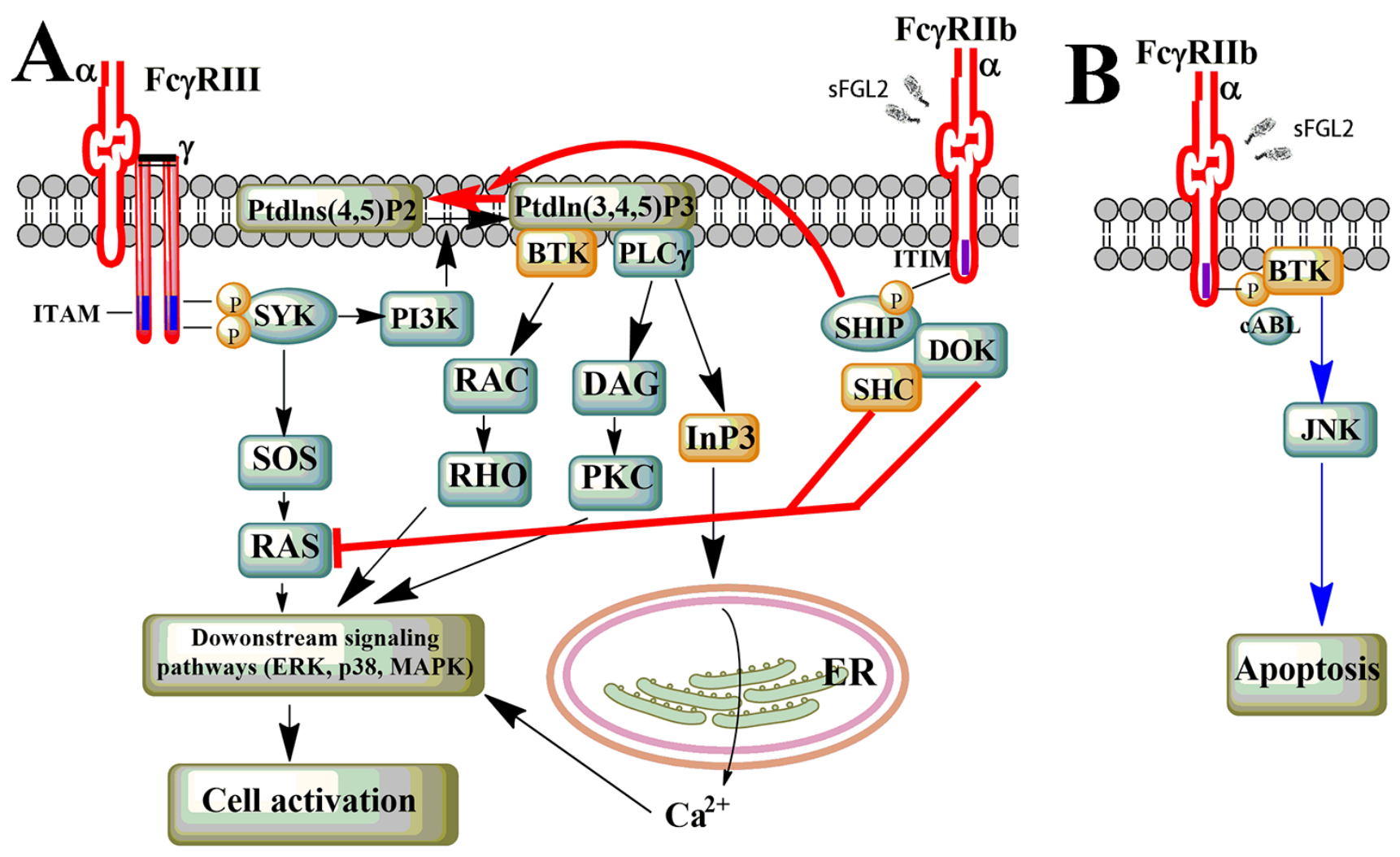

Figure 2: Potential sFGL2-related signaling pathway. A. ITAM/ITIM-dependent signaling pathway. Upon Fc $\gamma$ RIII crosslinking, LYN phosphorylates ITAM in the cytoplasmic domain of Fc $\gamma \mathrm{R} \gamma$-chain, this creates SRC homology 2 (SH2) docking sites for SYK, which subsequently activates PI3K and SOS, et al. Generation of Ptdlns $(3,4,5)$ P3 by PI3K recruits BTK and PLC $\gamma$, which further leads to activation of downstream kinases and the release of calcium from ER. Binding of sFGL2 to Fc $\gamma$ RIIb leads to phosphorylation of the ITIM in the cytoplasmic tail of FcyRIIb by LYN. This results in hydrolysis of Ptdlns $(3,4,5) \mathrm{P} 3$ into Ptdlns $(3,4,5) \mathrm{P} 2$ and inhibition of RAS, thus attenuating the activating-Fc $\gamma$ R-mediated cell activation. B. Triggering of Fc $\gamma$ RIIb can lead to cell apoptosis through ITIM- and SHIPindependent signaling pathways which involve the cABL kinase family, BTK, and JNK. 


\section{CLINICAL SIGNIFICANCE OF SFGL2}

\section{sFGL2 in transplantation}

Transplantation has been emerged as a viable therapeutic modality for the management of end-stage renal, cardiac, and liver failure. However, rejection still remains the biggest impediment to long-term survival of both allograft and recipients [63]. In line with that, seeking of novel immunosuppressive agents has become a hot issue in the field of transplant immunology [64, 65]. Numerous studies have shown that $\mathrm{CD} 4^{+} \mathrm{CD} 25^{+}$Tregs played critical roles in the induction and maintenance of transplant tolerance [66-69]. Molecular mechanisms of immune suppression by $\mathrm{CD} 4^{+} \mathrm{CD} 25^{+}$Tregs include modulation of cytokine microenvironment, metabolic disruption of the target cells, alteration of DC activating capacity and cytolysis [14, 70, 71]. As an effector molecule of $\mathrm{CD}^{+} \mathrm{CD} 25^{+}$Tregs, sFGL2 was also found to be involved in the induction of transplant tolerance. In tolerant cardiac and liver allografts, expression of sFGL2 as well as other tolerogenic set of genes such

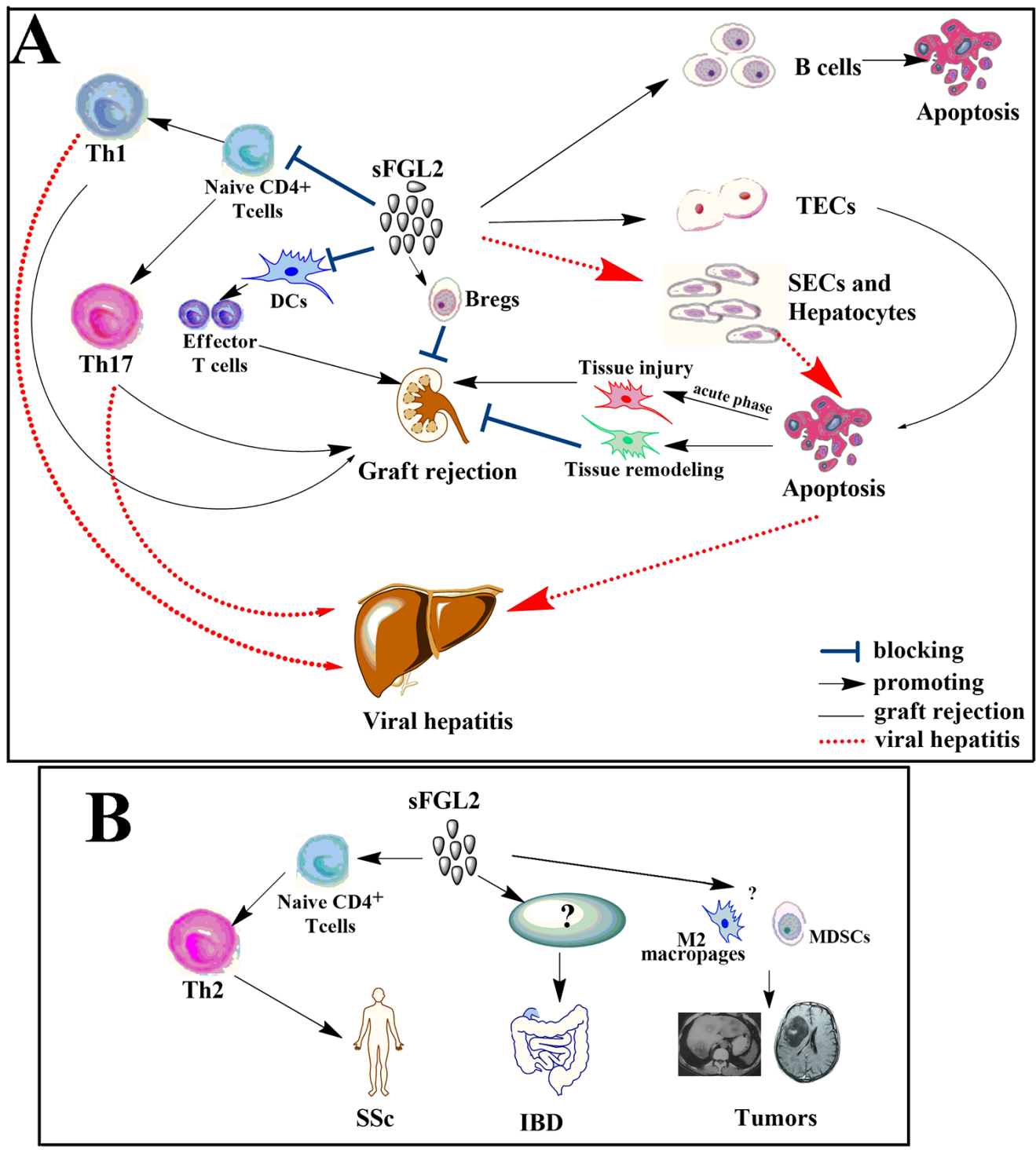

Figure 3: sFGL2 in transplantation, viral hepatitis and autoimmunity. A. By inducing apoptosis of TECs, repressing the maturation of DCs, promoting the differentiation and proliferation of Bregs, and inhibiting differentiation of Th1 as well as Th17 cells, sFGL2 exerts protective roles in the recovery phase after renal transplantation. However, apoptosis of TECs during the acute phase leads to kidney injury. In viral hepatitis, sFGL2 not only induces apoptosis of SECs and hepatocytes but also impairs anti-viral immunity by inhibiting differentiation of Th1 and Th17 cells, thus contributing to liver injury. B. sFGL2 plays a pathogenetic role in the development of SSc by promoting Th2 polarization. While roles of sFGL2 upregulation in IBD still need further investigation. sFGL2 might promote tumor progression by increasing the frequencies of myeloid-derived suppressor cells (MDSCs), M2 macrophages, upregulating the co-inhibitory receptor TIGIT expression, and inhibiting the anti-tumor effect of $\mathrm{CD} 8^{+} \mathrm{T}$ cells. 
as forkhead box P3 (Foxp3), cytotoxic T lymphocyteassociated protein 4 (CTLA4), and killer cell lectin-like receptor G1 (Klrg1) was significantly elevated [72]. Numbers and immunosuppressive activity of $\mathrm{CD}^{+}$Tregs were significantly elevated in cardiac allografts of $f g l 2$ transgenic mice, whereas proliferative ability of effector $\mathrm{T}$ cells to alloantigen stimulation was remarkably decreased [73]. Rapamycin-induced tolerance in $\mathrm{C} 3 \mathrm{H} / \mathrm{HeJ}$ mice transplanted with MHC-mismatched hearts from BALB/ cJ mice was associated with elevated plasma levels of sFGL2, and FoxP3/FGL2 dual positive $\mathrm{CD} 4{ }^{+} \mathrm{CD} 25^{+}$ Tregs were remarkably increased in tolerant allografts. It is notable that treatment with anti-FGL2 antibody could reverse the tolerizing effects of rapamycin in vitro and in vivo, indicating a key role of sFGL2 in transplantation tolerance induction [74]. Bezie et al. confirmed that sFGL2 expression was significantly upregulated in the graft and splenic $\mathrm{CD} 8^{+} \mathrm{CD} 45 \mathrm{RC}^{\text {low }}$ regulatory $\mathrm{T}$ cells of cardiac transplant rat at mRNA and protein level, and sFGL2 could induce long-term transplantation tolerance which was active and transferable by splenocytes [75]. The same group further observed in cardiac allotransplantation rats that FGL2 over-expression in vivo through virusmediated gene transfer resulted in inhibition of cardiac allograft rejection. The established allograft tolerance was transferable and Bregs induced by FGL2 over-expression were the main cells responsible for this effect [50]. As mentioned in a previous section, serum levels of sFGL2 were increased among renal allograft recipients with biopsy-proven acute rejection versus those with stable allograft or healthy controls. Moreover, serum sFGL2 levels were remarkably elevated in patients with antibodymediated than T-cell-mediated acute rejection episodes, and sFGL2 levels in patients with grade II T-cell-mediated rejection were significantly higher compared with that in patients with grade I T-cell-mediated rejection, indicating that sFGL2 expression in renal transplant patients with rejection was dependent on the pathological type and severity of the response [52]. Zhu and colleagues further discussed in their paper that decreased serum levels of sFGL2 in the stable group might be due to attraction of Tregs to the graft with sFGL2 secretion, reducing the content in the peripheral blood [43].

Apart from immune tolerance induction, sFGL2 could promote renal graft survival by inducing apoptosis of TECs. Data emerging from the literature suggested that TEC apoptosis was engaged in the pathogenetic process of kidney allograft rejection. Based on the results of experimental models of acute renal failure (ARF) in vivo, TEC apoptosis could be divided into two distinct phases. The first phase occurred shortly after the acute ischemic or nephrotoxic insult, which probably contributed to tubular cell loss and the tubular dysfunction associated with ARF. Whereas the second phase of apoptosis took place many days later during the recovery phase of ARF, which could provide some beneficial effects on the remodeling of injured tubules (Figure 3A) [76-78]. With regard to renal allograft, we might deduce that impact of sFGL2-induced TEC apoptosis was related to the stages after kidney transplant.

Infections are a major determinant of the outcome of organ transplantation and remain a significant cause of mortality among the recipients $[79,80]$. It is well known that current steroids or steroid-free immunosuppression schemes after organ transplantation could increase susceptibility to opportunistic infections [80-82]. Consequently, novel immunosuppressants are urgently needed to overcome or minimize adverse effects of immunosuppressive agents currently available. Liu et al. observed that sFGL2 injection into C57BL/6J mice could significantly prolong survival of skin allograft from $7.8 \pm 1.99 \mathrm{~d}$ to $15 \pm 2.56 \mathrm{~d}$ [39]. This finding indicated that sFGL2 was capable of inducing immune tolerance independent of prolonged immunosuppression, thus attenuating the risk of infection, secondary neoplasia, or cardiovascular disease. It was notable that monomeric sFGL2 possessed greater immunosuppressive activity than native oligomer sFGL2, so monomeric sFGL2 might be more potential for clinical use than native sFGL2 in term of its stronger immunosuppressive potency, higher permeability, and less antigenicity because of its lower molecular weight $[15,35]$.

\section{sFGL2 in hepatitis}

sFGL2 secreted by Tregs could suppress $\mathrm{T}$ cell immune responses to viral infections including hepatitis $\mathrm{C}$ virus (HCV) and HBV, thus might contribute to the development of viral hepatitis (Figure 3). Animal studies have demonstrated that plasma levels of sFGL2 in BALB/ cJ mice were significantly increased after murine hepatitis virus 3 (MHV-3) infection, and treatment with anti-FGL2 antibody or antisense plasmid complementary to the exon 1 of FGL2 gene could protect susceptible BALB/cJ mice against MHV-3-induced fulminant viral hepatitis $(\mathrm{FH})$ and mortality $[13,83]$. In patients with biopsy-proven HCV hepatitis, plasma levels of sFGL2 were considerably increased and correlated positively with $\mathrm{HCV}$ titers as well as degree of inflammation in the liver. Following an effective anti-viral therapy, levels of sFGL2 decreased significantly [23]. Compared with patients without cirrhosis or patients with inactive end stage alcoholic cirrhosis, HCV-patients with cirrhosis showed higher levels of sFGL2 [23]. Likewise, plasma levels of sFGL2 in patients with non-alcoholic steatohepatitis (NASH) and borderline NASH were significantly higher than that in healthy controls [84]. 


\section{sFGL2 in autoimmune diseases}

Systemic sclerosis ( $\mathrm{SSc}$ ) is generally identified as a Th2-dominant autoimmune disease [85]. Yanaba and coworkers recently reported that serum sFGL2 levels were increased remarkably in patients with SSc compared with healthy controls or systemic erythematosus lupus (SLE) [86]. By promoting Th2 polarization and inducing vascular endothelial damage in ischemia reperfusion injury, sFGL2 was thought to play a pathogenetic role in the development of SSc (Figure 3B).

Inflammatory bowel disease (IBD) is another autoimmune disorder which has been reported to have aberrant sFGL2 expression. The work of Dong revealed that mRNA and protein expression levels of FGL2 in peripheral blood mononuclear cells (PBMCs), as well as concentrations of sFGL2 in plasma were remarkably upregulated in both ulcerative colitis (UC) and Chohn's disease $(\mathrm{CD})$ patients compared with healthy controls. Moreover, UC and CD patients with active disease showed higher sFGL2 levels than those with inactive disease, and levels of sFGL2 correlated positively with disease activity indices, C-reactive protein (CRP), and erythrocyte sedimentation rate (ESR) [87]. Upregulation of sFGL2 in active $\mathrm{UC}$ and $\mathrm{CD}$ patients might be attributed to the insufficient compensation secreted by Tregs which failed to control the chronic inflammation.

It has been widely believed that aberrant Th profile is involved in the pathogenesis of a variety of autoimmune diseases. For example, primary immune thrombocytopenia (ITP) often exhibits a Th1 dominant profile together with elevated Th17 expression [88, 89]. In SLE patients, the role of Th1/Th2 balance in the development of SLE remains controversial, as both decreased and unchanged Th1 profile in peripheral blood has been shown previously $[90,91]$. However, Th17 subset in peripheral blood has been consistently reported to be increased in patients with SLE, and the elevated peripheral Th17 frequency correlated positively with the disease activity [92]. Furthermore, the pathogenetic role of elevated Th17 cells has also been established in several other autoimmune disorders, such as rheumatoid arthritis (RA) [93, 94] and psoriasis $[95,96]$. The critical role of sFGL2 in limiting Th1 and Th17 responses warrants further investigation in these autoimmune diseases.

\section{sFGL2 in tumors}

Tumors often constitute highly immunosuppressive microenvironments in which enhanced suppressive capacity of Tregs and impaired function of effector $\mathrm{T}$ cells coexist $[97,98]$. Based on the documented role of sFGL2 as a Treg effector molecule, it is reasonable to speculate that $\mathrm{sFGL2}$ might play a role in inhibiting anti-tumor immune responses. Indeed, Birkhäuser et al observed significantly elevated expression of FGL2 together with remarkably upregulated expression of CCL1, CXCL9, and HMGB1 in a murine renal carcinoma model which was not responsive to a DC-based vaccine therapy [99], and the altered gene expression profile was thought to contribute to evasion of immune surveillance in tumors [20]. More recently, Yan and colleagues reported that FLG2 contributed to the progression of glioblastoma multiforme (GBM) through inducing multiple immunosuppression mechanisms [100]. Compared with low-grade gliomas, GBM tumors had remarkably higher mRNA and protein levels of FGL2, and the elevated FGL2 levels were shown to be related to a lower overall survival rate in GBM patients. By transferring delayed brain tumor glioma cells into mice, the authors constructed GBM murine models and found that anti-FGL2 antibody treatment led to significantly prolonged survival time. Moreover, the increased frequencies of $\mathrm{CD} 4{ }^{+} \mathrm{CD} 39^{+}$Tregs, M2 macrophages, and myeloid-derived suppressor cells (MDSCs) were corrected after anti-FGL2 antibody treatment in GBM mice [100]. Further study by the same group identified that sFGL2 induced the co-inhibitory receptor TIGIT expression in brain-infiltrated T cells. Elevated TIGIT expression in T cells could suppress the anti-tumor immune responses in glioma, which might be a possible mechanism by which sFGL2 promoted tumor progression [101]. Additionally, Sun et al. reported that sFGL2 levels were considerably increased in hepatocellular carcinoma (HCC) patients. sFGL2 protein secreted by LX2 cells suppressed CD8 ${ }^{+}$ $\mathrm{T}$ cell proliferation of HCC patients in a dose-dependent manner in vitro, and blockade of sFGL2 with antibody enhanced the proliferation of $\mathrm{CD} 8^{+} \mathrm{T}$ cells significantly [102]. These data indicate that FGL2 is a key immunesuppressive modulator in tumors and may serve as a new target for tumor immunotherapy.

\section{sFGL2 in other diseases}

Aside from the above-mentioned diseases, roles of sFGL2 have been investigated in several other disorders. It has been reported that mRNA and protein levels of sFGL2 were significantly higher in mice experimentally infected with Echinococcus multilocularis [103]. The parasite loads, parasite proliferation activity, and proportion of parasite invaded liver were significantly lower in $f g l 2^{--}$ mice compared to WT mice, suggesting the crucial roles of sFGL2 in Echinococcus multilocularis infection [104, 105]. Additionally, microarray analysis of lymphatic tissue from HIV infected patients revealed that FGL2 upregualtion might be related to the transition from acute to asymptomatic stage [25]. 


\section{CONCLUDING REMARKS}

During the past few years, a flurry of emerging evidence has established the immunoregulatory role of sFGL2 as a novel effector molecule of Tregs, and considerable progress has been made in understanding the function of sFGL2 in normal and disease physiology. Nevertheless, much remains unclarified in regard to the upstream signals and precise downstream pathways that mediate the effects of sFGL2. Also, roles of sFGL2related biological processes such as apoptosis in infection or transplantation immunology still need to be further defined. Collectively, further exploration of sFGL2 will deepen our understanding about the induction and maintenance of immune tolerance, thus facilitating the development of novel strategies for the management of multiple immune-related diseases, such as graft rejection, viral hepatitis and autoimmunity.

\section{ACKNOWLEDGMENTS}

This work was supported by grants from Independent Innovation Foundation of Shandong University (No. 2012TS134), National Natural Science Foundation of China (No.81200344, 81470139).

\section{CONFLICTS OF INTEREST}

The authors declare no competing financial interests.

\section{REFERENCES}

1. Parr RL, Fung L, Reneker J, Myers-Mason N, Leibowitz JL and Levy G. Association of mouse fibrinogen-like protein with murine hepatitis virus-induced prothrombinase activity. Journal of virology. 1995; 69:5033-5038.

2. Smiley ST, King JA and Hancock WW. Fibrinogen stimulates macrophage chemokine secretion through tolllike receptor 4. J Immunol. 2001; 167:2887-2894.

3. Ruegg CR, Chiquet-Ehrismann R and Alkan SS. Tenascin, an extracellular matrix protein, exerts immunomodulatory activities. Proceedings of the National Academy of Sciences of the United States of America. 1989; 86:7437-7441.

4. Liu Y, Endo Y, Iwaki D, Nakata M, Matsushita M, Wada I, Inoue K, Munakata M and Fujita T. Human M-ficolin is a secretory protein that activates the lectin complement pathway. J Immunol. 2005; 175:3150-3156.

5. Thurston G, Suri C, Smith K, McClain J, Sato TN, Yancopoulos GD and McDonald DM. Leakage-resistant blood vessels in mice transgenically overexpressing angiopoietin-1. Science. 1999; 286:2511-2514.

6. Coito AJ, de Sousa $M$ and Kupiec-Weglinski JW. Fibronectin in immune responses in organ transplant recipients. Developmental immunology. 2000; 7:239-248.
7. Koyama T, Hall LR, Haser WG, Tonegawa S and Saito H. Structure of a cytotoxic T-lymphocyte-specific gene shows a strong homology to fibrinogen beta and gamma chains. Proceedings of the National Academy of Sciences of the United States of America. 1987; 84:1609-1613.

8. Chan CW, Kay LS, Khadaroo RG, Chan MW, Lakatoo S, Young KJ, Zhang L, Gorczynski RM, Cattral M, Rotstein O and Levy GA. Soluble fibrinogen-like protein 2/fibroleukin exhibits immunosuppressive properties: suppressing $\mathrm{T}$ cell proliferation and inhibiting maturation of bone marrowderived dendritic cells. J Immunol. 2003; 170:4036-4044.

9. Levy GA, Liu M, Ding J, Yuwaraj S, Leibowitz J, Marsden PA, Ning Q, Kovalinka A and Phillips MJ. Molecular and functional analysis of the human prothrombinase gene (HFGL2) and its role in viral hepatitis. The American journal of pathology. 2000; 156:1217-1225.

10. Chan CW, Chan MW, Liu M, Fung L, Cole EH, Leibowitz JL, Marsden PA, Clark DA and Levy GA. Kinetic analysis of a unique direct prothrombinase, fgl2, and identification of a serine residue critical for the prothrombinase activity. $\mathrm{J}$ Immunol. 2002; 168:5170-5177.

11. Yuwaraj S, Ding J, Liu M, Marsden PA and Levy GA. Genomic characterization, localization, and functional expression of FGL2, the human gene encoding fibroleukin: a novel human procoagulant. Genomics. 2001; 71:330-338.

12. Shalev I, Liu H, Koscik C, Bartczak A, Javadi M, Wong KM, Maknojia A, He W, Liu MF, Diao J, Winter E, Manuel $\mathrm{J}$, McCarthy D, et al. Targeted deletion of fgl2 leads to impaired regulatory $\mathrm{T}$ cell activity and development of autoimmune glomerulonephritis. J Immunol. 2008; 180:249-260.

13. Shalev I, Wong KM, Foerster K, Zhu Y, Chan C, Maknojia A, Zhang J, Ma XZ, Yang XC, Gao JF, Liu H, Selzner N, Clark DA, et al. The novel CD4+CD25+ regulatory $\mathrm{T}$ cell effector molecule fibrinogen-like protein 2 contributes to the outcome of murine fulminant viral hepatitis. Hepatology. 2009; 49:387-397.

14. Shevach EM. Mechanisms of foxp3+ T regulatory cellmediated suppression. Immunity. 2009; 30:636-645.

15. Liu H, Yang PS, Zhu T, Manuel J, Zhang J, He W, Shalev I, Zhang L, Cybulsky MI, Grant DR, Phillips MJ and Levy GA. Characterization of fibrinogen-like protein 2 (FGL2): monomeric FGL2 has enhanced immunosuppressive activity in comparison to oligomeric FGL2. The international journal of biochemistry \& cell biology. 2013; 45:408-418.

16. Li XL, Menoret S, Bezie S, Caron L, Chabannes D, Hill M, Halary F, Angin M, Heslan M, Usal C, Liang L, Guillonneau C, Le Mauff B, Cuturi MC, Josien R and Anegon I. Mechanism and localization of CD8 regulatory $\mathrm{T}$ cells in a heart transplant model of tolerance. J Immunol. 2010; 185:823-833.

17. Denning TL, Granger SW, Mucida D, Graddy $R$, Leclercq G, Zhang W, Honey K, Rasmussen JP, Cheroutre H, Rudensky AY and Kronenberg M. Mouse 
TCRalphabeta + CD8alphaalpha intraepithelial lymphocytes express genes that down-regulate their antigen reactivity and suppress immune responses. J Immunol. 2007; 178:4230-4239.

18. Chruscinski A, Sadozai H, Rojas-Luengas V, Bartczak A, Khattar R, Selzner N and Levy GA. Role of Regulatory T Cells (Treg) and the Treg Effector Molecule Fibrinogen-like Protein 2 in Alloimmunity and Autoimmunity. Rambam Maimonides medical journal. 2015; 6 .

19. Zhao Z, Wang L, Yang C, Zhao T, Li L, Hu L, Wu D, Rong R, Xu M and Zhu T. Soluble FGL2 induced by tumor necrosis factor-alpha and interferon-gamma in CD4+ T cells through MAPK pathway in human renal allograft acute rejection. The Journal of surgical research. 2013; 184:1114-1122.

20. Hu J, Yan J, Rao G, Latha K, Overwijk WW, Heimberger $\mathrm{AB}$ and Li S. The Duality of Fg12 - Secreted Immune Checkpoint Regulator Versus Membrane-Associated Procoagulant: Therapeutic Potential and Implications. International reviews of immunology. 2014.

21. Knackstedt M, Ding JW, Arck PC, Hertwig K, Coulam CB, August C, Lea R, Dudenhausen JW, Gorczynski RM, Levy GA and Clark DA. Activation of the novel prothrombinase, fg12, as a basis for the pregnancy complications spontaneous abortion and pre-eclampsia. Am J Reprod Immunol. 2001; 46:196-210.

22. Liu Y, Xu L, Zeng Q, Wang J, Wang M, Xi D, Wang X, Yang D, Luo X and Ning Q. Downregulation of FGL2/ prothrombinase delays HCCLM6 xenograft tumour growth and decreases tumour angiogenesis. Liver international. 2012; 32:1585-1595.

23. Foerster K, Helmy A, Zhu Y, Khattar R, Adeyi OA, Wong KM, Shalev I, Clark DA, Wong PY, Heathcote EJ, Phillips MJ, Grant DR, Renner EL, Levy GA and Selzner N. The novel immunoregulatory molecule FGL2: a potential biomarker for severity of chronic hepatitis $\mathrm{C}$ virus infection. Journal of hepatology. 2010; 53:608-615.

24. Shalev I, Selzner N, Helmy A, Foerster K, Adeyi OA, Grant DR and Levy G. The Role of FGL2 in the Pathogenesis and Treatment of Hepatitis C Virus Infection. Rambam Maimonides medical journal. 2010; 1:e0004.

25. Li Q, Smith AJ, Schacker TW, Carlis JV, Duan L, Reilly CS and Haase AT. Microarray analysis of lymphatic tissue reveals stage-specific, gene expression signatures in HIV-1 infection. J Immunol. 2009; 183:1975-1982.

26. Mendicino M, Liu M, Ghanekar A, He W, Koscik C, Shalev I, Javadi M, Turnbull J, Chen W, Fung L, Sakamoto $\mathrm{S}$, Marsden P, Waddell TK, et al. Targeted deletion of Fgl-2/fibroleukin in the donor modulates immunologic response and acute vascular rejection in cardiac xenografts. Circulation. 2005; 112:248-256.

27. Melnyk MC, Shalev I, Zhang J, Bartczak A, Gorczynski RM, Selzner N, Inman R, Marsden PA, Phillips MJ, Clark DA and Levy GA. The prothrombinase activity of FGL2 contributes to the pathogenesis of experimental arthritis. Scandinavian journal of rheumatology. 2011; 40:269-278.

28. Marsden PA, Ning Q, Fung LS, Luo X, Chen Y, Mendicino M, Ghanekar A, Scott JA, Miller T, Chan CW, Chan MW, He W, Gorczynski RM, et al. The Fgl2/fibroleukin prothrombinase contributes to immunologically mediated thrombosis in experimental and human viral hepatitis. The Journal of clinical investigation. 2003; 112:58-66.

29. Hancock WW, Szaba FM, Berggren KN, Parent MA, Mullarky IK, Pearl J, Cooper AM, Ely KH, Woodland DL, Kim IJ, Blackman MA, Johnson LL and Smiley ST. Intact type 1 immunity and immune-associated coagulative responses in mice lacking IFN gamma-inducible fibrinogenlike protein 2. Proceedings of the National Academy of Sciences of the United States of America. 2004; 101:30053010 .

30. Thierry-Mieg D and Thierry-Mieg J. AceView: a comprehensive cDNA-supported gene and transcripts annotation. Genome biology. 2006; 7 Suppl 1:S12 11-14.

31. Fung LS, Neil G, Leibowitz J, Cole EH, Chung S, Crow A and Levy GA. Monoclonal antibody analysis of a unique macrophage procoagulant activity induced by murine hepatitis virus strain 3 infection. The Journal of biological chemistry. 1991; 266:1789-1795.

32. Ghanekar A, Mendicino M, Liu H, He W, Liu M, Zhong R, Phillips MJ, Levy GA and Grant DR. Endothelial induction of fgl2 contributes to thrombosis during acute vascular xenograft rejection. J Immunol. 2004; 172:5693-5701.

33. Marazzi S, Blum S, Hartmann R, Gundersen D, Schreyer M, Argraves S, von Fliedner V, Pytela R and Ruegg C. Characterization of human fibroleukin, a fibrinogen-like protein secreted by T lymphocytes. J Immunol. 1998; 161:138-147.

34. Olson GE, Winfrey VP, NagDas SK and Melner MH. Region-specific expression and secretion of the fibrinogenrelated protein, fgl2, by epithelial cells of the hamster epididymis and its role in disposal of defective spermatozoa. The Journal of biological chemistry. 2004; 279:5126651274.

35. Yang G and Hooper WC. Physiological functions and clinical implications of fibrinogen-like 2: A review. World J Clin Infect Dis. 2013; 3:37-46.

36. Lafuse WP, Castle L, Brown D and Zwilling BS. The cytotoxic $\mathrm{T}$ lymphocyte gene FIBLP with homology to fibrinogen beta and gamma subunits is also induced in mouse macrophages by IFN-gamma. Cellular immunology. 1995; 163:187-190.

37. Cortes M, Wong E, Koipally J and Georgopoulos K. Control of lymphocyte development by the Ikaros gene family. Current opinion in immunology. 1999; 11:167-171.

38. Poli V. The role of $\mathrm{C} / \mathrm{EBP}$ isoforms in the control of inflammatory and native immunity functions. The Journal of biological chemistry. 1998; 273:29279-29282.

39. Liu H, Shalev I, Manuel J, He W, Leung E, Crookshank 
J, Liu MF, Diao J, Cattral M, Clark DA, Isenman DE, Gorczynski RM, Grant DR, et al. The FGL2FcgammaRIIB pathway: a novel mechanism leading to immunosuppression. European journal of immunology. 2008; 38:3114-3126.

40. Amigorena S, Bonnerot C, Drake JR, Choquet D, Hunziker W, Guillet JG, Webster P, Sautes C, Mellman I and Fridman WH. Cytoplasmic domain heterogeneity and functions of $\mathrm{IgG} \mathrm{Fc}$ receptors in B lymphocytes. Science. 1992; 256:1808-1812.

41. Nimmerjahn F and Ravetch JV. Fcgamma receptors as regulators of immune responses. Nature reviews Immunology. 2008; 8:34-47.

42. Blank U, Launay $\mathrm{P}$, Benhamou $\mathrm{M}$ and Monteiro RC. Inhibitory ITAMs as novel regulators of immunity. Immunological reviews. 2009; 232:59-71.

43. Wang L, Yang C, Xu M, Hu M, Wang X and Zhu T. The role of soluble fibrinogen-like protein 2 in transplantation: protection or damage. Transplantation. 2014; 97:12011206.

44. Khattar R, Luft O, Yavorska N, Shalev I, Phillips MJ, Adeyi O, Gao D, Bartczak A, Urbanellis P, Shyu W, Zhang J, Manuel J, Levy GA and Selzner N. Targeted deletion of FGL2 leads to increased early viral replication and enhanced adaptive immunity in a murine model of acute viral hepatitis caused by LCMV WE. PloS one. 2013; 8:e72309.

45. Yang S, Fujikado N, Kolodin D, Benoist C and Mathis D. Immune tolerance. Regulatory $\mathrm{T}$ cells generated early in life play a distinct role in maintaining self-tolerance. Science. 2015; 348:589-594.

46. Joller N, Lozano E, Burkett PR, Patel B, Xiao S, Zhu C, Xia J, Tan TG, Sefik E, Yajnik V, Sharpe AH, Quintana FJ, Mathis D, Benoist C, Hafler DA and Kuchroo VK. Treg cells expressing the coinhibitory molecule TIGIT selectively inhibit proinflammatory Th1 and Th17 cell responses. Immunity. 2014; 40:569-581.

47. Poussier P, Ning T, Banerjee D and Julius M. A unique subset of self-specific intraintestinal $\mathrm{T}$ cells maintains gut integrity. The Journal of experimental medicine. 2002; 195:1491-1497.

48. Rosser EC and Mauri C. Regulatory B cells: origin, phenotype, and function. Immunity. 2015; 42:607-612.

49. Rincon-Arevalo H, Sanchez-Parra CC, Castano D, Yassin L and Vasquez G. Regulatory B Cells and Mechanisms. International reviews of immunology. 2016; 35:156-176.

50. Bezie S, Picarda E, Tesson L, Renaudin K, Durand J, Menoret S, Merieau E, Chiffoleau E, Guillonneau C, Caron $\mathrm{L}$ and Anegon I. Fibrinogen-like protein 2/fibroleukin induces long-term allograft survival in a rat model through regulatory B cells. PloS one. 2015; 10:e119686.

51. Zhao Z, Yang C, Li L, Zhao T, Wang L, Rong R, Yang B, $\mathrm{Xu} \mathrm{M}$ and $\mathrm{Zhu} \mathrm{T}$. Increased peripheral and local soluble FGL2 in the recovery of renal ischemia reperfusion injury in a porcine kidney auto-transplantation model. Journal of translational medicine. 2014; 12:53.

52. Zhao Z, Yang C, Tang Q, Zhao T, Jia Y, Ma Z, Rong R, $\mathrm{Xu} \mathrm{M}$ and $\mathrm{Zhu} \mathrm{T}$. Serum level of soluble fibrinogen-like protein 2 in renal allograft recipients with acute rejection: a preliminary study. Transplantation proceedings. 2012; 44:2982-2985.

53. Zhao Z, Yang C, Wang L, Li L, Zhao T, Hu L, Rong R, $\mathrm{Xu} \mathrm{M}$ and $\mathrm{Zhu} \mathrm{T}$. The regulatory $\mathrm{T}$ cell effector soluble fibrinogen-like protein 2 induces tubular epithelial cell apoptosis in renal transplantation. Exp Biol Med (Maywood). 2014; 239:193-201.

54. Garraud O, Borhis G, Badr G, Degrelle S, Pozzetto B, Cognasse F and Richard Y. Revisiting the B-cell compartment in mouse and humans: more than one B-cell subset exists in the marginal zone and beyond. BMC immunology. 2012; 13:63.

55. Smith KG and Clatworthy MR. FcgammaRIIB in autoimmunity and infection: evolutionary and therapeutic implications. Nature reviews Immunology. 2010; 10:328343.

56. Odin JA, Edberg JC, Painter CJ, Kimberly RP and Unkeless JC. Regulation of phagocytosis and $[\mathrm{Ca} 2+]$ i flux by distinct regions of an Fc receptor. Science. 1991; 254:1785-1788.

57. Willcocks LC, Smith KG and Clatworthy MR. Low-affinity Fcgamma receptors, autoimmunity and infection. Expert reviews in molecular medicine. 2009; 11:e24.

58. Takai T. Roles of $F c$ receptors in autoimmunity. Nature reviews Immunology. 2002; 2:580-592.

59. Ono M, Bolland S, Tempst P and Ravetch JV. Role of the inositol phosphatase SHIP in negative regulation of the immune system by the receptor Fc(gamma)RIIB. Nature. 1996; 383:263-266.

60. Pearse RN, Kawabe T, Bolland S, Guinamard R, Kurosaki $\mathrm{T}$ and Ravetch JV. SHIP recruitment attenuates Fc gamma RIIB-induced B cell apoptosis. Immunity. 1999; 10:753760.

61. Tzeng SJ, Bolland S, Inabe K, Kurosaki T and Pierce SK. The B cell inhibitory Fc receptor triggers apoptosis by a novel c-Abl family kinase-dependent pathway. The Journal of biological chemistry. 2005; 280:35247-35254.

62. Ono M, Okada H, Bolland S, Yanagi S, Kurosaki T and Ravetch JV. Deletion of SHIP or SHP-1 reveals two distinct pathways for inhibitory signaling. Cell. 1997; 90:293-301.

63. Ingulli E. Mechanism of cellular rejection in transplantation. Pediatr Nephrol. 2010; 25:61-74.

64. Bakr MA, Nagib AM and Donia AF. Induction immunosuppressive therapy in kidney transplantation. Experimental and clinical transplantation. 2014; 12 Suppl 1:60-69.

65. Ruiz P, Maldonado P, Hidalgo Y, Gleisner A, Sauma D, Silva C, Saez JJ, Nunez S, Rosemblatt M and Bono MR. Transplant tolerance: new insights and strategies for long-term allograft acceptance. Clinical \& developmental 
immunology. 2013; 2013:210506.

66. Wood KJ and Sakaguchi S. Regulatory $\mathrm{T}$ cells in transplantation tolerance. Nature reviews Immunology. 2003; 3:199-210.

67. Kang SM, Tang Q and Bluestone JA. CD4+CD25+ regulatory $\mathrm{T}$ cells in transplantation: progress, challenges and prospects. American journal of transplantation. 2007; 7:1457-1463.

68. Long E and Wood KJ. Regulatory T cells in transplantation: transferring mouse studies to the clinic. Transplantation. 2009; 88:1050-1056.

69. Edozie FC, Nova-Lamperti EA, Povoleri GA, Scotta C, John S, Lombardi G and Afzali B. Regulatory T-cell therapy in the induction of transplant tolerance: the issue of subpopulations. Transplantation. 2014; 98:370-379.

70. Sakaguchi S, Miyara M, Costantino CM and Hafler DA. FOXP3+ regulatory T cells in the human immune system. Nature reviews Immunology. 2010; 10:490-500.

71. Sakaguchi S, Yamaguchi $\mathrm{T}$, Nomura $\mathrm{T}$ and Ono $\mathrm{M}$. Regulatory T cells and immune tolerance. Cell. 2008; 133:775-787.

72. Xie L, Ichimaru N, Morita M, Chen J, Zhu P, Wang J, Urbanellis P, Shalev I, Nagao S, Sugioka A, Zhong L, Nonomura N, Takahara S, Levy GA and Li XK. Identification of a novel biomarker gene set with sensitivity and specificity for distinguishing between allograft rejection and tolerance. Liver transplantation. 2012; 18:444-454.

73. Bartczak A, Chruscinski A, Mendicino M, Liu H, Zhang J, He W, Amir AZ, Nguyen A, Khattar R, Sadozai H, Lobe CG, Adeyi O, Phillips MJ, et al. Overexpression of Fibrinogen-Like Protein 2 Promotes Tolerance in a Fully Mismatched Murine Model of Heart Transplantation. American journal of transplantation. 2016; 16:1739-1750.

74. Urbanellis P, Shyu W, Khattar R, Wang J, Zakharova A, He W, Sadozai H, Amir AZ, Shalev I, Phillips MJ, Adeyi O, Ross H, Grant D, Levy GA and Chruscinski A. The regulatory $\mathrm{T}$ cell effector molecule fibrinogen-like protein 2 is necessary for the development of rapamycin-induced tolerance to fully $\mathrm{MHC}$-mismatched murine cardiac allografts. Immunology. 2015; 144:91-106.

75. Bézie S, Ménoret S, Tesson L, Li XL, Usal C, Anegon I and Caron L. Immunosuppressive role of fibrinogen-like protein 2 (FGL2) in CD8+regulatory T cells-mediated longterm graft survival. Journal of translational medicine. 2011; 9:O5

76. Lieberthal W, Koh JS and Levine JS. Necrosis and apoptosis in acute renal failure. Seminars in nephrology. 1998; 18:505-518.

77. Bonegio $\mathrm{R}$ and Lieberthal W. Role of apoptosis in the pathogenesis of acute renal failure. Current opinion in nephrology and hypertension. 2002; 11:301-308.

78. Sanz AB, Santamaria B, Ruiz-Ortega M, Egido J and Ortiz A. Mechanisms of renal apoptosis in health and disease. Journal of the American Society of Nephrology. 2008;
19:1634-1642.

79. Sanders-Pinheiro H, da Silveira ST, Carminatti M, Braga LS, Marsicano EO, Magalhaes GL, Carvalho LF, Filho GF, Magacho EJ, Colugnati F and Bastos MG. Excessive immunosuppression in kidney transplant patients: prevalence and outcomes. Transplantation proceedings. 2012; 44:2381-2383.

80. Fishman JA. Infection in solid-organ transplant recipients. The New England journal of medicine. 2007; 357:26012614.

81. Miro JM, Blanes M, Norman F and Martin-Davila P. Infections in solid organ transplantation in special situations: HIV-infection and immigration. Enfermedades infecciosas y microbiologia clinica. 2012; 30 Suppl 2:7685.

82. Luan FL, Steffick DE and Ojo AO. Steroid-free maintenance immunosuppression in kidney transplantation: is it time to consider it as a standard therapy? Kidney international. 2009; 76:825-830.

83. Zhu C, Sun Y, Luo X, Yan W, Xi D and Ning Q. Novel $\mathrm{mfgl} 2$ antisense plasmid inhibits murine fgl2 expression and ameliorates murine hepatitis virus type 3-induced fulminant hepatitis in BALB/cJ mice. Human gene therapy. 2006; 17:589-600.

84. Colak Y, Senates E, Ozturk O, Yilmaz Y, Coskunpinar E, Kahraman OT, Sahin O, Zemheri E, Enc FY, Ulasoglu C, Kiziltas S, Kurdas OO and Tuncer I. Plasma fibrinogen-like protein 2 levels in patients with non-alcoholic fatty liver disease. Hepato-gastroenterology. 2011; 58:2087-2090.

85. Hasegawa M, Fujimoto M, Kikuchi K and Takehara K. Elevated serum levels of interleukin 4 (IL-4), IL-10, and IL-13 in patients with systemic sclerosis. The Journal of rheumatology. 1997; 24:328-332.

86. Yanaba K, Asano Y, Noda S, Akamata K, Aozasa N, Taniguchi T, Takahashi T, Ichimura Y, Toyama T, Sumida H, Kuwano Y, Tada Y, Sugaya M, Kadono T and Sato S. Increased circulating fibrinogen-like protein 2 in patients with systemic sclerosis. Clinical rheumatology. 2013; 32:43-47.

87. Dong X, Ye X, Chen X, Chen T, Xie S, Li Q, Lin X and Huang $Z$. Intestinal and peripheral fibrinogen-like protein 2 expression in inflammatory bowel disease. Digestive diseases and sciences. 2014; 59:769-777.

88. Liu X, Hou Y and Peng J. Advances in immunopathogenesis of adult immune thrombocytopenia. Frontiers of medicine. 2013; 7:418-424.

89. Liu XG, Ren J, Yu Y, Sun L, Shi Y, Qin P, Yang L, Ma SH, Dong XY, Ma DX, Qu X, Guo CS, Chen CY, Hou M and Peng J. Decreased expression of interleukin-27 in immune thrombocytopenia. British journal of haematology. 2011; 153:259-267.

90. Funauchi M, Ikoma S, Enomoto $\mathrm{H}$ and Horiuchi A. Decreased Th1-like and increased Th2-like cells in systemic lupus erythematosus. Scandinavian journal of 
rheumatology. 1998; 27:219-224.

91. Chang DM, Su WL and Chu SJ. The expression and significance of intracellular $\mathrm{T}$ helper cytokines in systemic lupus erythematosus. Immunological investigations. 2002; 31:1-12.

92. Shin MS, Lee N and Kang I. Effector T-cell subsets in systemic lupus erythematosus: update focusing on Th17 cells. Current opinion in rheumatology. 2011; 23:444-448.

93. Leipe J, Grunke M, Dechant C, Reindl C, Kerzendorf U, Schulze-Koops H and Skapenko A. Role of Th17 cells in human autoimmune arthritis. Arthritis and rheumatism. 2010; 62:2876-2885

94. Azizi G, Jadidi-Niaragh F and Mirshafiey A. Th17 Cells in Immunopathogenesis and treatment of rheumatoid arthritis. International journal of rheumatic diseases. 2013; 16:243253.

95. Benham $\mathrm{H}$, Norris $\mathrm{P}$, Goodall J, Wechalekar MD, FitzGerald O, Szentpetery A, Smith M, Thomas R and Gaston H. Th17 and Th22 cells in psoriatic arthritis and psoriasis. Arthritis research \& therapy. 2013; 15:R136.

96. Elloso MM, Gomez-Angelats M and Fourie AM. Targeting the Th17 pathway in psoriasis. Journal of leukocyte biology. 2012; 92:1187-1197.

97. Chen DS and Mellman I. Oncology meets immunology: the cancer-immunity cycle. Immunity. 2013; 39:1-10.

98. Whiteside TL. What are regulatory T cells (Treg) regulating in cancer and why? Seminars in cancer biology. 2012; 22:327-334.

99. Birkhauser FD, Koya RC, Neufeld C, Rampersaud EN, Lu X, Micewicz ED, Chodon T, Atefi M, Kroeger N, Chandramouli GV, Li G, Said JW, McBride WH, et al. Dendritic cell-based immunotherapy in prevention and treatment of renal cell carcinoma: efficacy, safety, and activity of Ad-GM.CAIX in immunocompetent mouse models. J Immunother. 2013; 36:102-111.

100. Yan J, Kong LY, Hu J, Gabrusiewicz K, Dibra D, Xia $\mathrm{X}$, Heimberger AB and Li S. FGL2 as a Multimodality Regulator of Tumor-Mediated Immune Suppression and Therapeutic Target in Gliomas. Journal of the National Cancer Institute. 2015; 107.

101. Yan J, Gabrusiewicz K, Xia X, Heimberger AB and Li S. FGL2 promotes tumor progression via inducing TIGIT expression on T cells in tumor microenvironment of glioma. J Immunol. 2016; 196:72.10.
102. Sun Y, Xi D, Ding W, Wang F, Zhou H and Ning Q. Soluble FGL2, a novel effector molecule of activated hepatic stellate cells, regulates T-cell function in cirrhotic patients with hepatocellular carcinoma. Hepatology international. 2014; 8:567-575.

103. Gottstein B, Wittwer M, Schild M, Merli M, Leib SL, Muller N, Muller J and Jaggi R. Hepatic gene expression profile in mice perorally infected with Echinococcus multilocularis eggs. PloS one. 2010; 5:e9779.

104. Wang J, Vuitton DA, Muller N, Hemphill A, Spiliotis M, Blagosklonov O, Grandgirard D, Leib SL, Shalev I, Levy G, Lu X, Lin R, Wen H and Gottstein B. Deletion of Fibrinogen-like Protein 2 (FGL-2), a Novel CD4+ CD25+ Treg Effector Molecule, Leads to Improved Control of Echinococcus multilocularis Infection in Mice. PLoS neglected tropical diseases. 2015; 9:e0003755.

105. Wang $\mathrm{J}$ and Gottstein B. Immunoregulation in larval Echinococcus multilocularis infection. Parasite immunology. 2016; 38:182-192.

106. Buckner JH. Mechanisms of impaired regulation by $\mathrm{CD} 4(+) \mathrm{CD} 25(+) \mathrm{FOXP3}(+)$ regulatory $\mathrm{T}$ cells in human autoimmune diseases. Nature reviews Immunology. 2010; 10:849-859.

107. Ligocki AJ and Niederkorn JY. Advances on Non-CD4 + Foxp3+ T Regulatory Cells: CD8+, Type 1, and Double Negative $\mathrm{T}$ Regulatory Cells in Organ Transplantation. Transplantation. 2015; 99:1553-1559.

108. Corazza N, Muller S, Brunner T, Kagi D and Mueller C. Differential contribution of Fas- and perforin-mediated mechanisms to the cell-mediated cytotoxic activity of naive and in vivo-primed intestinal intraepithelial lymphocytes. J Immunol. 2000; 164:398-403.

109. Fanchiang SS, Cojocaru R, Othman M, Khanna R, Brooks MJ, Smith T, Tang X, Maricic I, Swaroop A and Kumar V. Global expression profiling of peripheral Qa-1-restricted CD8alphaalpha+TCRalphabeta+ regulatory $\mathrm{T}$ cells reveals innate-like features: implications for immune-regulatory repertoire. Human immunology. 2012; 73:214-222. 